\title{
Uji Beberapa Konsentrasi Tepung Bunga Cengkeh (Syzygium aromaticum (L.) Merr. dan Perry) untuk Mengendalikan Hama Sitophilus zeamais M. pada Biji Jagung di Penyimpanan
}

\author{
Rini Chindy Faqy*, Rusli Rustam \\ Fakultas Pertanian, Universitas Riau \\ * chindyfaqy@gmail.com
}

\begin{abstract}
Abstrak. Penelitian ini bertujuan untuk mendapatkan konsentrasi tepung bunga cengkeh terbaik dalam mengendalikan hama $S$. zeamais pada biji jagung di penyimpanan. Penelitian menggunakan Rancangan Acak Lengkap (RAL) dengan empat perlakuan dan lima ulangan sehingga diperoleh 20 unit percobaan. Perlakuan merupakan konsentrasi tepung bunga cengkeh, yaitu 0\%, 3\%, 6\% dan 9\%. Parameter pengamatan meliputi waktu awal kematian, lethal time 50 (LT50), mortalitas harian, mortalitas total, penyusutan berat biji jagung, kerusakan biji jagung, dan pertambahan individu $S$. zeamais pada generasi pertama. Hasil penelitian menunjukkan bahwa pemberian tepung bunga cengkeh konsentrasi $9 \%$ menyebabkan terjadinya waktu awal kematian tercepat yaitu 303,60 jam, mortalitas harian 4\%, mortalitas total $24 \%$, penyusutan berat biji jagung 3,80\%, kerusakan biji jagung $12,86 \%$, dan rata-rata jumlah pertambahan individu S. zeamais 23,00 ekor. Kesimpulan dari penelitian ini bahwa pemberian tepung bunga cengkeh konsentrasi $9 \%$ cenderung memberikan hasil terbaik untuk mematikan S. zeamais, namun belum efektif dalam mengendalikan hama S. zeamais di penyimpanan.
\end{abstract}

Kata Kunci: Sitophilus zeamais, Syzygium aromaticum, Zea mays

\section{PENDAHULUAN}

Jagung (Zea mays L.) merupakan komoditas pangan unggulan kedua setelah padi dan memiliki banyak kegunaan yaitu sebagai bahan pangan pokok, pembuatan tepung, minyak, bahkan sebagai pakan ternak. Kerusakan mekanik selama proses pasca panen dapat mencapai $25-37 \%$ yang menyebabkan hilangnya sebagian hasil panen (Warisno, 1998). Hal lain yang juga menjadi penyebab rendahnya produksi dan kehilangan hasil adalah adanya serangan hama di lapangan maupun di tempat penyimpanan. Usaha peningkatan produksi pada aspek prapanen selama ini sudah dilakukan sedangkan perhatian pada pengelolaan pasca panen masih kurang, sehingga menyebabkan bahan yang disimpan mengalami penyusutan baik secara kualitas maupun kuantitas. Soekarna (1984) menyatakan bahwa kerusakan hasil setelah panen tercatat lebih besar dibandingkan dengan sebelum panen, yaitu antara 10-54 \% setiap tahun. Kerusakan pasca panen disebabkan oleh berbagai faktor diantaranya yaitu faktor fisik, kimia, fisiologis dan biologis (Sonyaratri, 2006). Faktor biologis merupakan faktor yang sering menyebabkan kerusakan biji-bijian di gudang penyimpanan. Kerusakan akibat faktor biologis disebabkan oleh serangan serangga hama. Menurut Wagiman (2014) salah satu serangga hama yang sering menyerang biji jagung di gudang penyimpanan yaitu Sitophilus zeamais Motschulsky.

Hama Sitophilus zeamais paling banyak menimbulkan kerugian, khususnya pada komoditi jagung, hal ini terjadi karena serangga tersebut dapat menyerang sejak saat menjelang panen sampai produknya berada dalam penyimpanan (Mangoendihardjo, 1978). Serangan hama ini menyebabkan biji berlubang, cepat pecah dan hancur menjadi tepung. Hal ini ditandai dengan adanya tepung pada butiran yang terserang. Biji dan tepung dipersatukan oleh air liur larva sehingga kualitas biji menurun atau rusak sama sekali (Surtikanti, 2004).

To cite this article: Faqy, R.C., dan R. Rustam. 2019. Uji Beberapa Konsentrasi Tepung Bunga Cengkeh (Syzygium aromaticum (L.) Merr. dan Perry) untuk Mengendalikan Hama Sitophilus zeamais M. pada Biji Jagung di Penyimpanan. Unri Conference Series: Agriculture and Food Security 1: 67-77. https://doi.org/10.31258/unricsagr.1a9 
Menurut Surtikanti et al. (1999) dalam Surtikanti (2004) bahwa dari 287 galur Sl jagung yang diuji, setelah disimpan 1,5 bulan ternyata ada 274 galur yang memperlihatkan kerusakan 50-100\%, 11 galur mengalami kerusakan 30-49\%, dan 2 galur dengan kerusakan $<10 \%$. Oleh sebab itu untuk mengurangi kerusakan biji jagung pada penyimpanan akibat serangan hama $S$. zeamais ini, perlu dilakukan pengendalian hama pasca panen.

Pengendalian hama pasca panen yang paling efisien dan umum dilakukan adalah dengan menggunakan pestisida kimia dengan cara fumigasi. Fumigasi adalah salah satu cara pengendalian yang efektif untuk mengendalikan hama pada bahan simpanan. Senyawa kimia sintetik yang biasa digunakan sebagai fumigan adalah metil bromida dan karbon tetrachlorida (Kartasapoetra, 1987). Penggunaan metil bromida memiliki efek samping yang berbahaya bagi konsumen karena metil bromida dapat bereaksi secara kimia dengan beberapa komoditas pangan dan menimbulkan residu bromida organik (Wagiman, 2014).

Alternatif pengendalian yang dapat digunakan untuk mengatasi kekurangan dari pestisida kimia yaitu pestisida nabati. Pestisida nabati relatif tidak meracuni manusia dan hewan karena berasal dari tumbuhan yang sifatnya mudah terurai sehingga tidak menimbulkan residu. Selain itu, pestisida nabati relatif mudah dalam penggunaannya dan tidak menimbulkan efek samping pada lingkungan, bahan bakunya dapat diperoleh dengan mudah dan murah serta dapat dibuat dengan cara yang sederhana sehingga mudah diadopsi oleh petani (Kartasapoetra, 1993). Salah satu tanaman yang bersifat insektisida nabati adalah cengkeh (Syzygium aromaticum).

Cengkeh (Syzygium aromaticum) mengandung eugenol, saponin, flavonoid dan tanin (Nurdjannah, 2004). Menurut Hart (1990) dalam Iffah et al. (2008) menyatakan bahwa eugenol bekerja sebagai fumigan yang akan menguap dan menembus secara langsung ke integumen serangga sehingga dapat melemahkan dan mengganggu sistem saraf yang berperan menurunkan enzim asetilkolineterase. Minyak cengkeh mempunyai sifat repellent serta dapat menghambat aktivitas makan (anti feedant) beberapa hama gudang seperti Tribolium castaneum dan Sitophilus zeamais (Kim et al., 2004; Thorsell et al., 2006). Manohara et al. (1999) menyatakan bahwa eugenol cengkeh dapat dimanfaatkan sebagai bahan baku pestisida nabati, mengingat beberapa hasil penelitian menunjukkan bahwa senyawa eugenol efektif untuk mengendalikan nematoda, jamur patogen, bakteri maupun serangga hama. Sedangkan Aisyahesti (2013) menyatakan bahwa pemberian tepung bunga cengkeh dengan konsentrasi 6\% mampu mengendalikan hama kumbang Callosobruchus maculatus dengan mortalitas total $92,50 \%$ di penyimpanan.

Penelitian ini bertujuan untuk mendapatkan konsentrasi tepung bunga cengkeh (Syzygium aromaticum (L.) Merr. dan Perry) yang terbaik untuk mengendalikan hama Sitophilus zeamais M. pada biji jagung di penyimpanan.

\section{KAJIAN PUSTAKA}

Jagung merupakan sumber pangan dunia selain gandum dan padi. Selain untuk pangan juga digunakan untuk pakan ternak. Sekitar 60\% jagung digunakan untuk bahan baku industri, 57\% diantaranya digunakan untuk pakan ternak (Badan Penelitian dan Pengembangan Pertanian, 2004). Biji jagung sering mengalami kerusakan dalam proses penyimpanan. Masalah kadar air, suhu dan kelembaban udara sangat menentukan daya simpan. Menurut Susmawati (2014) kadar air biji jagung yang aman dalam penyimpanan yaitu 12\%. Makin rendah tingkat kadar air benih, makin lama benih tersebut dapat mempertahankan viabilitasnya. Salah satu serangan hama yang dapat menimbulkan kerusakan dan penurunan mutu biji jagung selama penyimpanan yaitu S. zeamais (Surtikanti dan Suherman, 2003).

Hama Sitophilus zeamais merupakan hama penting pada biji-bijian di penyimpanan dan tersebar luas di daerah tropis. Serangan hama ini menyebabkan biji berlubang, cepat pecah serta hancur menjadi tepung sehingga kualitas biji menjadi menurun (Surtikanti, 2004). Klasifikasi S. zeamais yaitu Kingdom: Animalia, Filum: Arthropoda, Kelas: Insekta, Ordo: Coleoptera, Famili: Curculionidae, Genus: Sitophilus, Spesies: Zeamais, Nama Ilmiah: Sitophilus zeamais M. (Sudarmo, 2005).

S. zeamais menyerang biji-biji jagung yang telah masak di lapangan sehingga tongkol jagung berlubanglubang. Setiap lubang yang digerek, dimasuki satu butir telur kemudian lubang ditutup kembali dengan zat seperti gelatin yang berfungsi sebagai sumbat telur. Telur akan menetas dalam beberapa hari menjadi larva dan memakan bagian dalam inti biji, kemudian menjadi kepompong selanjutnya menjadi kumbang dewasa. Serangan S. zeamais ini dapat menimbulkan kerugian yang sangat besar (Nyoman, 2005).

Hasil penelitian Putri (2004) menyatakan pengendalian hama S. zeamais dengan aplikasi tepung daun sirsak pada konsentrasi $2 \%$ pada media oligidik dapat mematikan dan menghambat perkembangan $S$. 
zeamais. Pada pengamatan 10 minggu setelah perlakuan tidak ada satu serangga S. zeamais baik imago maupun turunan pertama (F1) yang mampu bertahan hidup. Pada tanpa perlakuan, populasi S. zeamais mencapai 6.067 ekor turunan pertama (F1). Hasil penelitian Hasnah dan Usamah (2010) menyatakan bahwa esktrak bawang putih juga dapat mematikan dan mengendalikan hama S. zeamais dengan mortalitas $85 \%$ pada konsentrasi $6 \%$. Selain daun tanaman sirsak dan bawang putih, bunga cengkeh juga berpotensi sebagai insektisida nabati.

Tanaman cengkeh termasuk dalam Kingdom: Plantae, Divisi: Spermatophyta, Subdivisi: Angiospermae, Kelas: Dicotyledoneae, Ordo: Myrtales, Famili: Myrtaceae, Genus: Syzigium, Spesies: aromaticum, Nama ilmiah: Syzygium aromaticum (Octavianty dan Suwarto, 2010).

Minyak cengkeh mengandung beberapa senyawa volatil seperti eugenol, eugenol asetat, dan metil eugenol. Dari ketiga senyawa tersebut, eugenol adalah komponen utama penyusun minyak cengkeh. Kadar eugenol pada minyak daun cengkeh mencapai $70 \%$, sedangkan pada bunga cengkeh mencapai $90 \%$ (Bhuiyan et al. 2010). Pemanfaatan eugenol dapat dilakukan dengan cara pemberian langsung menggunakan daun atau bunga cengkeh yang dihancurkan dalam bentuk tepung, dan cara lain dengan mengolah daun dan bunga menjadi minyak cengkeh (Wiratno, 2010).

Kemampuan bunga cengkeh sebagai insektisida telah dilaporkan oleh Zeng., et al. (2010) bahwa 2metoksi-4-(2-propenil)-fenol yang merupakan komponen utama minyak esensial dari cengkeh memiliki kemampuan repellent terhadap hama Rhyzopertha dominica dan Tribolium castaneum dengan rata-rata repellent yaitu $93 \%$ dan $97 \%$.

Pemberian minyak atsiri cengkeh dengan konsentrasi $10 \%$ dapat memberikan persentase kematian paling tinggi (100\%) terhadap ulat bulu (Mika et al., 2012). Mustika dan Rachmat (1994) dalam Balfas (2008) melaporkan bahwa tepung bunga cengkeh mempunyai efektifitas yang sama dengan pestisida sintetik terhadap nematoda Radopholus similis dan Meloydogine incognita.

\section{METODE}

Penelitian dilakukan secara eksperimen dengan menggunakan Rancangan Acak Lengkap (RAL) dengan empat perlakuan dan lima ulangan sehingga diperoleh 20 unit percobaan. Terdiri dari dua percobaan yang diparalelkan, percobaan paralel pertama 20 unit dan percobaan paralel kedua 20 unit. Perlakuan terdiri dari tepung bunga cengkeh dengan konsentrasi yang berbeda, yaitu: G0 = Konsentrasi tepung bunga cengkeh 0\%; $\mathrm{G} 1=$ Konsentrasi tepung bunga cengkeh 3\%; G2 = Konsentrasi tepung bunga cengkeh 6\%; G3 = Konsentrasi tepung bunga cengkeh 9\%.

\section{Pengadaan biji jagung}

Biji jagung diperoleh dari Balai Benih Induk (BBI) di Marpoyan Damai varietas Sukma Raga. Jumlah biji jagung yang digunakan yaitu sebanyak $4.000 \mathrm{~g}$, dimana $2.000 \mathrm{~g}$ digunakan untuk pengamatan waktu awal kematian, lethal time 50 (LT50), mortalitas harian dan mortalitas total. Sedangkan $2.000 \mathrm{~g}$ digunakan untuk pengamatan penyusutan berat biji jagung, kerusakan biji jagung dan pertambahan individu S. zeamais.

\section{Pengukuran kadar air}

Pengukuran kadar air dilakukan dengan mengambil sampel yaitu $100 \mathrm{~g}$ jagung dengan tiga kali pengambilan. Sampel dimasukkan kedalam amplop padi dengan ukuran $28 \times 18 \mathrm{~cm}$ yang telah dilubangi sebanyak lima lubang. Selanjutnya dimasukkan ke dalam oven dan dipanaskan selama 48 jam dengan suhu $70^{\circ} \mathrm{C}$. Setelah 48 jam jagung ditimbang kembali.

\section{Perbanyakan S. zeamais M.}

Imago S. zeamais diambil sebanyak 100 ekor dan dimasukkan ke dalam kotak plastik yang telah berisi jagung sebanyak $500 \mathrm{~g}$ sebagai bahan makanan untuk perbanyakan. Setelah sepuluh hari imago dipindahkan ke kotak plastik lain yang berisi $500 \mathrm{~g}$ biji jagung. Telur yang telah diletakkan oleh imago pada pakan biji jagung sebelumnya dipelihara sampai muncul imago turunan pertama (F1) yang berumur dua hari. Imago F1 inilah yang digunakan sebagai serangga hama uji.

\section{Pembuatan tepung bunga cengkeh}

Bunga cengkeh dikering anginkan. Selanjutnya diblender hingga halus kemudian diayak menjadi tepung. Setelah itu tepung bunga cengkeh ditimbang masing-masing sebanyak $3 \mathrm{~g}, 6 \mathrm{~g}$, dan 9 g sesuai konsentrasi perlakuan. Lalu masing-masing tepung bunga cengkeh tersebut dimasukan ke dalam kemasan yang berbahan kertas tissu kasar berbentuk bundar dengan diameter ukuran kemasan $7 \mathrm{~cm}$. 


\section{Aplikasi}

Biji jagung terlebih dahulu ditimbang sebanyak $100 \mathrm{~g}$ yang akan digunakan sebagai bahan makanan hama uji $S$. zeamais yang dimasukkan ke dalam tiap-tiap stoples plastik. Kemudian imago $S$. zeamais turunan pertama (F1) yang berumur dua hari dimasukkan ke dalam tiap-tiap kotak plastik tersebut sebanyak sepuluh ekor yang terdiri dari lima ekor jantan dan 5 ekor betina. Imago $S$. zeamais yang telah dimasukkan ke dalam tiaptiap kotak tersebut dibiarkan selama $24 \mathrm{jam}$, hal ini agar $S$. zeamais dapat beradaptasi terlebih dahulu. Setelah 24 jam, kemudian sachet tepung bunga cengkeh yang telah ditimbang sesuai dengan konsentrasi perlakuan diletakkan dipermukaan pada tiap-tiap kotak plastik yang telah diisi dengan biji jagung dan imago S. zeamais.

\section{Parameter Pengamatan}

Parameter yang diamati terdiri dari dua unit percobaan. Unit percobaan pertama terdiri dari waktu awal kematian, lethal time 50 (LT50), mortalitas harian, mortalitas total. Sedangkan unit percobaan kedua terdiri dari penyusutan berat biji jagung, kerusakan biji jagung, pertambahan individu S. zeamais M. dan suhu dan kelembaban.

\section{Analisis Data}

Data yang diperoleh akan dianalisis secara statistik dengan menggunakan sidik ragam. Hasil sidik ragam dilanjutkan dengan uji lanjut BNT pada taraf 5\%. Sedangkan mortalitas harian S. zeamais dianalisis secara statistik deskriptif dan disajikan dalam bentuk grafik.

\section{HASIL DAN PEMBAHASAN}

\section{Waktu Awal Kematian Sitophilus zeamais M. (Jam)}

Hasil sidik ragam menunjukkan bahwa pemberian beberapa konsentrasi tepung bunga cengkeh (Syzygium aromaticum) terhadap hama $S$. zeamais pada biji jagung di penyimpanan berpengaruh nyata terhadap waktu awal kematian. Hasil rata-rata waktu awal kematian setelah diuji lanjut BNT pada taraf 5\% dapat dilihat pada Tabel 1.

Tabel 1. Rata-rata waktu awal kematian S. zeamais pada biji jagung di penyimpanan dengan pemberian konsentrasi tepung bunga cengkeh setelah ditransformasikan

\begin{tabular}{cc}
\hline Konsentrasi tepung bunga cengkeh $(\%)$ & Rata-rata waktu awal kematian S. zeamais (jam) \\
\hline $0 \%$ & $720,00 \mathrm{a}$ \\
$3 \%$ & $560,20 \mathrm{a}$ \\
$6 \%$ & $312,60 \mathrm{~b}$ \\
$9 \%$ & $303,60 \mathrm{~b}$
\end{tabular}

Angka-angka pada lajur yang dikuti oleh huruf kecil yang tidak sama berbeda nyata menurut uji BNT pada taraf 5\%

Tabel 1 menunjukkan bahwa waktu awal kematian perlakuan tepung bunga cengkeh konsentrasi 9\% yaitu 303,60 jam berbeda tidak nyata dengan perlakuan konsentrasi 6\% yaitu 312,60 jam, namun berbeda nyata dengan konsentrasi 3\% yaitu 560,20 jam dan konsentrasi $0 \%$ yaitu 720 jam. Hal ini diduga karena imago $S$. zeamais masih mampu mentolerir senyawa aktif yang terkandung di dalam tepung bunga cengkeh. Hal ini disebabkan semakin tinggi konsentrasi maka semakin banyak kandungan bahan aktif yang terdapat dalam tepung bunga cengkeh. Sesuai dengan pendapat Sari (2013) bahwa peningkatan konsentrasi berbanding lurus dengan peningkatan bahan racun, sehingga daya bunuh semakin tinggi.

Waktu awal kematian S. zeamais setelah pemberian tepung bunga cengkeh konsentrasi 9\% yaitu 303,60 jam setelah aplikasi cenderung lebih lama dibandingkan dengan hasil penelitian Aisyahesti (2013) menunjukkan bahwa pemberian tepung bunga cengkeh dengan konsentrasi $6 \%$ pada kacang hijau mampu mengendalikan hama kumbang Callosobruchus maculatus lebih baik dengan waktu awal kematian lebih cepat yaitu 4 jam setelah aplikasi. Hal ini diduga karena siklus hidup S. zeamais yang lebih lama yaitu 31-37 hari (Surtikanti, 2004), sedangkan C. maculatus hanya 21-28 hari (Beck dan Blumer, 2013). Hal ini didukung oleh Natawigena (1990) bahwa faktor internal seperti sifat mempertahankan diri, siklus hidup, dan umur imago yang berbeda-beda mampu mempengaruhi perkembangan hama. Faktor lain yang menyebabkan waktu awal kematian $S$. zeamais cenderung lebih lama yaitu karena luasan ventilasi yang besar pada kotak percobaan menyebabkan bahan aktif eugenol yang terkandung di dalam tepung bunga cengkeh lebih cepat menguap terlepas ke udara, sehingga hanya sedikit bahan aktif yang terhirup oleh $S$. zeamais. 
Perlakuan konsentrasi tepung bunga cengkeh 3\% menunjukkan awal kematian S. zeamais 560,20 jam setelah aplikasi dan berbeda tidak nyata dengan perlakuan konsentrasi $0 \%$ yaitu 720,00 jam setelah aplikasi. Hal ini disebabkan karena pada perlakuan konsentrasi yang rendah maka kandungan senyawa aktif eugenol lebih sedikit dibandingkan dengan perlakuan konsentrasi yang tinggi, sehingga waktu yang dibutuhkan lebih lama dalam mematikan imago S. zeamais. Pendapat ini sesuai dengan Aminah (1995) yang menyatakan bahwa tinggi rendahnya suatu konsentrasi akan mempengaruhi kandungan bahan aktif yang selanjutnya berpengaruh terhadap waktu kematian serangga uji tersebut.

\section{Lethal Time 50 (LT50) (Jam)}

Hasil penelitian setelah dilakukan analisis sidik ragam menunjukkan bahwa pemberian beberapa konsentrasi tepung bunga cengkeh berpengaruh tidak nyata terhadap lethal time 50 (LT50). Hasil uji lanjut BNT pada taraf 5\% dapat dilihat pada Tabel 2.

Tabel 2. Rata-rata lethal time 50 (LT50) S. zeamais pada biji jagung di penyimpanan dengan pemberian konsentrasi tepung bunga cengkeh

\begin{tabular}{cc}
\hline Konsentrasi tepung bunga cengkeh (\%) & Rata-rata lethal time S. zeamais (jam) \\
\hline $0 \%$ & $720,00 \mathrm{a}$ \\
$3 \%$ & $720,00 \mathrm{a}$ \\
$6 \%$ & $720,00 \mathrm{a}$ \\
$9 \%$ & $720,00 \mathrm{a}$ \\
\hline
\end{tabular}

Angka-angka pada lajur yang dikuti oleh huruf kecil yang tidak sama berbeda nyata menurut uji BNT pada taraf 5\%

Tabel 2 menunjukkan bahwa perlakuan tepung bunga cengkeh konsentrasi 9\%, 6\%, 3\% dan 0\% berbeda tidak nyata antar perlakuan yaitu 720 jam setelah aplikasi. Pemberian tepung bunga cengkeh pada setiap konsentrasi yang digunakan mampu mematikan $S$. zeamais, namun persentase kematiannya tidak mencapai 50\% sampai akhir penelitian. Menurut Sari (2013) peningkatan konsentrasi berbanding lurus dengan peningkatan bahan racun, sehingga daya bunuh semakin tinggi, namun pada pemberian tepung bunga cengkeh dengan konsentrasi yang semakin tinggi tidak menunjukkan perbedaan terhadap nilai LT50 sampai akhir penelitian (720 jam). Hal ini disebabkan oleh semakin panjang umur imago serangga maka semakin kuat daya tahan hidup serangga, sedangkan semakin pendek umur imago maka semakin lemah daya tahan hidup imago serangga tersebut. Hasil penelitian Manueke et al. (2015) menunjukkan bahwa lama hidup imago jantan S. zeamais yaitu 109,25 hari dan imago betina $S$. zeamais yaitu 125,75 hari dibandingkan dengan umur imago C. maculatus yang hanya 10-14 hari (Balitkabi, 2016).

Faktor lain yang menyebabkan peningkatan konsentrasi berbeda tidak nyata antar perlakuan adalah bahan aktif eugenol yang terdapat dalam tepung bunga cengkeh lebih banyak terlepas keluar dari pada ke dalam kotak perlakuan. Faktor tersebut yang diduga menyebabkan pemberian beberapa konsentrasi tepung bunga cengkeh tidak berpengaruh nyata terhadap parameter lethal time 50 (LT50). Hartati (2012) menyatakan bahwa insektisida nabati yang diaplikasikan secara fumigan yang bekerja mengganggu sistem kerja saraf tidak membunuh serangga hama secara cepat. Senyawa eugeol yang terdapat pada tepung bunga cengkeh mudah menguap sehingga belum efektif untuk mematikan serangga $S$. zeamais dengan cepat. Hal ini sesuai dengan pendapat Setyowati (2004) bahwa bahan-bahan nabati cepat menguap dan residunya mudah hilang, hal ini disebabkan karena senyawa kimia yang ada dalam bahan nabati mudah terdegradasi oleh lingkungan. Koul et al. (2008) juga menyatakan bahwa keefektifan pestisida minyak atsiri umumnya lebih rendah dibandingkan dengan pestisida kimia sintetik dan kerjanya lebih lambat.

\section{Mortalitas Harian Sitophilus zeamais M. (\%)}

Hasil pengamatan mortalitas harian S. zeamais selama 720 jam (30 hari) menunjukkan bahwa perlakuan dengan pemberian konsentrasi tepung bunga cengkeh berfluktuasi terhadap kematian S. zeamais. Perbedaan waktu kematian serangga menyebabkan terjadinya fluktuasi mortalitas harian yang berbeda pada setiap pemberian konsentrasi tepung bunga cengkeh. Hal ini sesuai dengan pendapat Natawigena (2000) menyatakan bahwa setiap makhluk hidup mempunyai batas toleransi terhadap racun dimana makhluk tersebut tidak mati. Fluktuasi mortalitas harian S. zeamais dapat dilihat pada Gambar 1. 


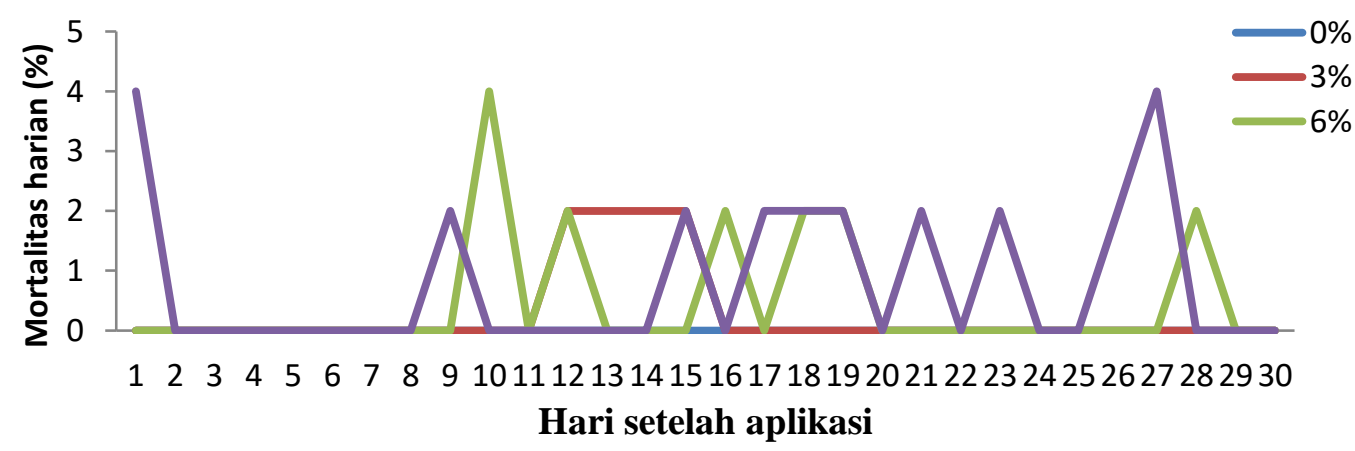

Gambar 1. Fluktuasi mortalitas harian imago S. zeamais setelah pemberian beberapa konsentrasi tepung bunga cengkeh

Gambar 1 menunjukkan fluktuasi mortalitas harian S. zeamais pada setiap harinya. Hari pertama setelah aplikasi konsentrasi $9 \%$ tepung bunga cengkeh menyebabkan mortalitas harian sebesar $4 \%$, sedangkan pada perlakuan lainnya belum terdapat $S$. zeamais yang mati. Pemberian tepung bunga cengkeh konsentrasi $9 \%$ merupakan konsentrasi tertinggi yang digunakan karena daya racunnya tinggi sehingga menyebabkan $S$. zeamais cepat mengalami kematian. Pendapat ini sesuai dengan hasil penelitian Aisyahesti (2013) bahwa pemberian konsentrasi tepung bunga cengkeh tertinggi menyebabkan serangga cepat mengalami kematian. Pemberian tepung bunga cengkeh konsentrasi $9 \%$ menyebabkan mortalitas harian pada hari kedua sampai hari kedelapan tidak mengalami kematian, namun mengalami fluktuasi pada hari kesembilan hingga akhir penelitian. Hal ini diduga pada hari kedua sampai hari kedelapan S. zeamais masih mampu mentolerir bahan aktif yang terkandung dalam tepung bunga cengkeh. Namun pada hari kesembilan sampai akhir pengamatan, diduga senyawa aktif eugenol telah terakumulasi dalam tubuh $S$. zeamais, sehingga menyebabkan kematian yang tinggi pada hari ke-27. Hal ini diperkuat dengan pernyataan Dadang dan Prijono (2008) bahwa suatu serangga memiliki kepekaan terhadap senyawa bioaktif dapat dipengaruhi oleh kemampuan metabolik serangga yang bisa menyingkirkan dan menguraikan bahan racun dari tubuhnya.

Puncak mortalitas harian pada pemberian konsentrasi 6\% terjadi pada hari ke-10 dan mengalami penurunan pada hari ke-12 sebesar 2\% hingga akhir penelitian. Pada perlakuan 3\% tepung bunga cengkeh mortalitas harian pada hari ke-12 sampai hari ke-15 masing-masing sebesar 2\% dan tidak terjadi kematian lagi sampai akhir penelitian.

Persentase mortalitas harian S. zeamais yang rendah disebabkan karena senyawa aktif eugenol yang terdapat pada tepung bunga cengkeh mudah terurai. Pendapat ini sesuai dengan pernyataan Saenong (2013) bahwa salah satu kelemahan insektisida nabati yaitu daya racunnya rendah. Selain itu senyawa eugenol merupakan senyawa dari kelompok fenol yang mudah menguap (Nurjannah et al., 2013). Hal ini terlihat pada pengamatan pada hari ke-29 dan hari ke-30 S. zeamais tidak terjadi kematian.

\section{Mortalitas Total Sitophilus zeamais M. (\%)}

Hasil penelitian setelah dilakukan analisis sidik ragam menunjukkan bahwa pemberian beberapa konsentrasi tepung bunga cengkeh berpengaruh nyata terhadap mortalitas total $S$. zeamais. Hasil uji lanjut BNT pada taraf 5\% dapat dilihat pada Tabel 3.

Tabel 3. Rata-rata mortalitas total S. zeamais pada biji jagung di penyimpanan dengan pemberian konsentrasi tepung bunga cengkeh setelah ditransformasikan

$\begin{array}{cr}\text { Konsentrasi tepung bunga cengkeh }(\%) & \text { Mortalitas total } S . z e a r \\ 0 & 0,00 \mathrm{~d} \\ 3 & 8,00 \mathrm{c} \\ 6 & 14,00 \mathrm{~b} \\ 9 & 24,00 \mathrm{a}\end{array}$

Angka-angka pada lajur yang dikuti oleh huruf kecil yang tidak sama adalah berbeda nyata menurut uji BNT pada taraf 5\%

Tabel 3 menunjukkan bahwa pada perlakuan konsentrasi tepung bunga cengkeh $9 \%$ menyebabkan mortalitas total sebesar $24 \%$ dan berbeda nyata dengan perlakuan konsentrasi $6 \%$ sebesar $14 \%$, konsentrasi $3 \%$ sebesar $8 \%$ dan kosentrasi $0 \%$ sebesar $0 \%$. Hal ini diduga semakin tinggi konsentrasi maka semakin banyak kandungan bahan aktif yang terdapat dalam tepung bunga cengkeh. 
Perlakuan tepung bunga cengkeh dengan konsentrasi $9 \%$ memiliki mortalitas total lebih tinggi dalam mematikan S. zeamais yaitu sebesar $24 \%$. Kandungan senyawa aktif eugenol yang terdapat dalam tepung bunga cengkeh masuk sebagai racun fumigan dan bekerja mengganggu sistem saraf dalam mematikan hama kumbang S. zeamais. Menurut Wiratno (2010) kandungan senyawa eugenol pada bunga cengkeh mencapai 90\%. Senyawa eugenol menghambat kerja enzim asetilkolinesterase yang berfungsi menghidrolisis asetilkolin yang berperan menghantarkan impuls syaraf. Asetilkolin akan mengalami hidrolisis menjadi kolin dan asam asetat dengan bantuan enzim asetilkolinesterase (Lee et al., 2001). Apabila kerja enzim asetilkolinesterase terhambat, maka akan terjadi penumpukan asetilkolin sehingga menyebabkan serangga mengalami gejala tremor (gemetar), konvulsi (kejang-kejang), dan paralisis (kelumpuhan) yang pada akhirnya menyebabkan kematian (Djojosumarto 2008).

Mortalitas total yang dihasilkan pada penelitian ini tergolong rendah jika dibandingkan dengan hasil penelitian Aisyahesti (2013) penggunaan tepung bunga cengkeh sebagai fumigan mampu mengendalikan hama C. maculatus F. dengan mortalitas total 92,50\%. Hal ini diduga karena bahan aktif eugenol yang terdapat dalam tepung bunga cengkeh lebih cepat mengalami penguapan, sehingga hanya sedikit bahan aktif yang terhirup oleh S. zeamais. Konsentrasi $9 \%$ tepung bunga cengkeh belum efektif digunakan sebagai pestisida nabati yang bersifat fumigan. Pernyataan ini sesuai dengan pendapat Dadang dan Prijono (2008) yang menyatakan bahwa pestisida nabati dikatakan efektif apabila perlakuan tersebut dapat mengakibatkan kematian serangga uji melebihi $80 \%$.

Penyusutan Berat Biji Jagung (\%)

Hasil penelitian setelah dilakukan analisis sidik ragam menunjukkan bahwa pemberian beberapa konsentrasi tepung bunga cengkeh berpengaruh nyata terhadap penyusutan berat biji jagung. Hasil uji lanjut BNT pada taraf 5\% dapat dilihat pada Tabel 4.

Tabel 4. Rata-rata penyusutan berat biji jagung di penyimpanan dengan pemberian beberapa konsentrasi tepung bunga cengkeh setelah ditransformasikan Konsentrasi tepung bunga cengkeh (\%) Penyusutan berat biji jagung (\%)

\begin{tabular}{cc}
\hline Konsentrasi tepung bunga cengkeh $(\%)$ & Penyusutan berat biji jagung (\%) \\
\hline 0 & $10,50 \mathrm{a}$ \\
3 & $8,36 \mathrm{a}$ \\
6 & $7,70 \mathrm{ab}$ \\
9 & $3,80 \mathrm{~b}$ \\
\hline
\end{tabular}

Angka-angka yang diikuti oleh huruf kecil yang tidak sama adalah berbeda nyata menurut hasil uji BNT pada taraf 5\%

Tabel 4 menunjukkan bahwa perlakuan tepung bunga cengkeh dengan konsentrasi $9 \%$ menyebabkan penyusutan berat biji jagung sebesar 3,80\% dan berbeda tidak nyata dengan perlakuan konsentrasi $6 \%$ yaitu sebesar 7,70\%, namun berbeda nyata dengan kosentrasi 3\% yaitu sebesar 8,36\% dan 0\% sebesar 10,50\%. Hal ini disebabkan senyawa aktif eugenol tepung bunga cengkeh mampu menghambat aktifitas makan $S$. zeamais sehingga berpengaruh terhadap penyusutan berat biji jagung. Senyawa aktif eugenol yang terkandung dalam tepung bunga cengkeh bekerja sebagai racun saraf dengan menghambat aliran impuls saraf pada akson, sehingga menyebabkan terjadinya perubahan aktifitas $S$. zeamais dan mengganggu proses makannya yang mengakibatkan menurunnya daya makan $S$. zeamais sehingga lama kelamaan imago lemah dan mati.

Perlakuan tepung bunga cengkeh konsentrasi $0 \%$ menyebabkan penyusutan berat biji jagung paling tinggi sebesar $10,50 \%$. Hal ini disebabkan karena rendahnya kematian serangga $S$. zeamais sehingga aktifitas makan serangga uji tinggi dan menyebabkan penyusutan berat biji jagung akan semakin tinggi. Hal ini didukung oleh Murdolelono dan Hosang (2006) menyatakan bahwa semakin banyak jumlah S. zeamais maka semakin besar persentase kerusakan biji dan persentase susut bobotnya, selain itu semakin besar persentase kerusakan biji maka persentase susut bobotnya juga semakin besar.

Kerusakan Biji Jagung (\%)

Hasil penelitian setelah dilakukan analisis sidik ragam menunjukkan bahwa pemberian beberapa konsentrasi tepung bunga cengkeh berpengaruh nyata terhadap kerusakan biji jagung. Hasil uji lanjut BNT pada taraf 5\% dapat dilihat pada Tabel 5.

Tabel 5. Rata-rata kerusakan biji jagung di penyimpanan dengan pemberian beberapa konsentrasi tepung bunga cengkeh setelah ditransformasikan

Konsentrasi tepung bunga cengkeh (\%) Kerusakan biji jagung (\%)

$$
0 \quad 21,52 \mathrm{a}
$$




$\begin{array}{ll}3 & 19,00 \mathrm{a} \\ 6 & 15,22 \mathrm{a} \\ 9 & 12,86 \mathrm{~b}\end{array}$

Angka-angka pada lajur yang dikuti oleh huruf kecil yang tidak sama berbeda nyata menurut uji BNT pada taraf 5\%

Tabel 5 menunjukkan bahwa perlakuan tepung bunga cengkeh dengan konsentrasi 9\% menyebabkan kerusakan biji jagung sebesar 12,86\% dan berbeda nyata dengan perlakuan konsentrasi $6 \%$ yaitu sebesar $15,22 \%$, konsentrasi 3\% yaitu sebesar $19 \%$ dan konsentrasi $0 \%$ yaitu sebesar $21,52 \%$. Hal ini diduga perlakuan tepung bunga cengkeh konsentrasi $9 \%$ memiliki kandungan senyawa aktif eugenol yang tinggi sehingga menyebabkan rendahnya kerusakan biji jagung yang didukung oleh parameter mortalitas total yang cenderung lebih tinggi yaitu sebesar 24\%. Pernyataan ini diperkuat oleh Harbone (1979) dalam Nursal (1997) menyatakan bahwa konsentrasi yang lebih tinggi maka pengaruh yang ditimbulkan juga semakin tinggi, disamping itu daya kerja suatu senyawa sangat ditentukan oleh besarnya konsentrasi.

Biji jagung yang rusak akibat $S$. zeamais akan terdapat lubang-lubang kecil pada biji jagung tersebut. Hal ini didukung oleh pendapat Chapman (1998) bahwa S. zeamais meletakkan telur dalam butiran jagung dengan cara menggerek, setelah menetas larva tetap berada dalam biji dan memakan isi biji sehingga biji berlubang. Sukoco (1998) juga menyatakan bahwa larva berkembang dengan memakan bagian dalam biji jagung. Winarno dan Jennie (1983) menambahkan tingkat kerusakan oleh hama serangga pada suatu bahan simpan tergantung pada jumlah serangga yang ada serta kemampuan merusaknya. Semakin tinggi populasi hama yang terdapat pada bahan simpan, maka semakin tinggi pula tingkat kerusakan yang ditimbulkannya.

\section{Pertambahan Individu Sitophilus zeamais M. (ekor)}

Hasil penelitian setelah dilakukan analisis sidik ragam menunjukkan bahwa pemberian beberapa konsentrasi tepung bunga cengkeh berpengaruh nyata terhadap pertambahan individu S. zeamais. Hasil uji lanjut BNT pada taraf 5\% dapat dilihat pada Tabel 6 .

Tabel 6. Rata-rata pertambahan individu S. zeamais dengan pemberian beberapa konsentrasi tepung bunga cengkeh

\begin{tabular}{cc}
\hline Konsentrasi tepung bunga cengkeh $(\%)$ & Rata-rata pertambahan individu (ekor) \\
\hline 0 & $32,80 \mathrm{a}$ \\
3 & $28,60 \mathrm{a}$ \\
6 & $27,60 \mathrm{ab}$ \\
9 & $23,00 \mathrm{~b}$ \\
\hline
\end{tabular}

Angka-angka yang dikuti oleh huruf kecil yang tidak sama adalah berbeda nyata menurut hasil uji BNT pada taraf 5\%

Tabel 6 menunjukkan bahwa konsentrasi 9\% tepung bunga cengkeh menyebabkan rata-rata pertambahan individu S. zeamais sebesar 23,00 ekor dan berbeda tidak nyata dengan perlakuan konsentrasi $6 \%$ tepung bunga cengkeh yaitu sebesar 27,60 ekor, namun berbeda nyata dengan konsentrasi 3\% yaitu sebesar 28,60 ekor dan konsentrasi $0 \%$ yaitu sebesar 32,80 ekor. Hal ini diduga karena perlakuan konsentrasi $9 \%$ S. zeamais masih mampu mentolerir bahan aktif eugenol, sehingga dalam menghasilkan pertambahan individu S. zeamais memiliki respon yang sama dengan perlakuan konsentrasi tepung bunga cengkeh 6\%. Dadang dan Prijono (2008) menyatakan bahwa suatu serangga memiliki kepekaan terhadap senyawa bioaktif dapat dipengaruhi oleh kemampuan metabolik serangga yang bisa menyingkirkan dan menguraikan bahan racun dari tubuhnya.

Perlakuan tepung bunga cengkeh konsentrasi $9 \%$ menyebabkan pertambahan individu S. zeamais yang cenderung lebih rendah dibandingkan dengan kosentrasi $6 \%$, konsentrasi $3 \%$ dan konsentrasi $0 \%$. Hal ini berkaitan dengan persentase penyusutan berat biji jagung dan kerusakan biji jagung yang cenderung lebih rendah, sehingga semakin rendah persentase penyusutan berat biji jagung dan kerusakan biji jagung yang dihasilkan maka aktifitas makan $S$. zeamais akan menjadi berkurang dan menyebabkan tingkat pertambahan individu $S$. zeamais juga akan semakin rendah. Hal ini juga didukung oleh parameter mortalitas total pada perlakuan tepung bunga cengkeh konsentrasi $9 \%$ cenderung lebih tinggi yaitu sebesar $24 \%$ sehingga menyebabkan penyusutan berat biji jagung, kerusakan biji jagung dan pertambahan individu S. zeamais tergolong rendah.

Kartasapoetra (1987) menyatakan bahwa faktor lingkungan dapat mempengaruhi pertambahan individu $S$. zeamais diantaranya yaitu kadar air pada produk penyimpanan, tempat penyimpanan, suhu dan kelembaban. Kondisi yang optimum untuk pertumbuhan dan perkembangan S. zeamais adalah pada suhu 17-34oC, 
dengan suhu optimal 28oC serta kelembaban relatif antara 45-100\% dan kelembaban optimal 70\% (Pranata, 1979).

Hasil penelitian menunjukkan rata-rata suhu selama penyimpanan satu bulan yaitu $27,13 \mathrm{oC}$, rata-rata kelembaban selama sebulan yaitu 82,8\% dan kadar air biji jagung yaitu 13,31\%. Susmawati (2014) menyatakan kadar biji jagung yang optimum dalam penyimpanan yaitu $12 \%$. Faktor lingkungan seperti suhu, kelembaban dan kadar air biji jagung yang terdapat di laboratorium mampu mendukung pertambahan populasi S. zeamais. Hal ini didukung oleh Kastanja (2007) yang menyatakan semakin tinggi tingkat kadar air maka semakin tinggi intensitas kerusakan yang disebabkan oleh hama S. zeamais dan begitu juga sebaliknya jika kadar air semakin rendah maka intensitas kerusakan juga rendah.

\section{KESIMPULAN}

Berdasarkan hasil penelitian pemberian tepung bunga cengkeh konsentrasi 9\% cenderung memberikan hasil yang terbaik dengan waktu awal kematian 303,60 jam, mortalitas total sebesar 24\%, penyusutan biji jagung sebesar $3,80 \%$, kerusakan biji jagung sebesar $12,86 \%$ dan rata-rata jumlah pertambahan individu $S$. zeamais sebanyak 23,00 ekor.

\section{DAFTAR PUSTAKA}

Aisyahesti. 2013. Uji Beberapa Konsentrasi Tepung Bunga Cengkeh (Syzygium aromaticum (L.) Merr. dan Perry) terhadap Mortalitas Hama Callosobruchus maculatus F. pada Kacang Hijau di Penyimpanan. Skripsi (Tidak dipublikasikan). Universitas Riau. Pekanbaru.

Aminah, S. N. 1995. Evaluasi Tiga Jenis Tumbuhan sebagai Insektisida dan Repelen terhadap Nyamuk di Laboratorium. Tesis (Tidak dipublikasikan). Institut Pertanian Bogor. Bogor.

Badan Penelitian dan Pengembangan Pertanian. 2004. Laporan Tahunan 2003 Inovasi Pertanian untuk Kesejahteraan Petani. Jakarta.

Balitkabi. 2016. Callosobruchus maculatus Hama Gudang Kacang Hijau. Jawa Timur.

Balfas, R. 2008. Potensi minyak daun cengkeh sebagai pengendali Planococcus minor (Mask) (Pseudococcidae: Homoptera) pada tanaman lada. Balai Penelitian Tanaman Obat dan Aromatik. Buletin Litro. 19(1): 78-85.

Beck, C.W., and L.S. Blumer. 2013. Life Cycle of Bean Beetles, Callosobruchus maculatus (Coleoptera: Chrysomelidae). Carolina Biological Supply Company.

Bhuiyan, M.Z.I., J. Begum, N.C. Nandi, and F. Akter. 2010. Constituents of the essential oil from leaves and buds of clove (Syzigium caryophyllatum L.). African Journal of Plant Science 4(11): 451-454.

Chapman, R.F. 1998. The Insect Structure and Function. Third Edition. London: Edward Arnold Publisher Ltd.

Dadang, dan D. Prijono. 2008. Insektisida Nabati Prinsip, Pemanfaatan, dan Pengembangan. Bogor: Departemen Proteksi Tanaman Institut Pertanian Bogor.

Djojosumarto, P. 2008. Pestisida dan Aplikasinya. Jakarta: Agro Media Pustaka.

Hartati, S.Y. 2012. Prospek pengembangan minyak atsiri sebagai pestisida nabati. Jurnal Perspektif 11(1): 45-58.

Hasnah, dan U. Hanif. 2010. Efektivitas Ekstrak Bawang Putih Terhadap Mortalitas Sitophilus zeamais M. pada Jagung di Penyimpanan. Jurnal Floratek 5: 1-10.

Iffah, D., D.J. Gunandini, dan A. Kardinan. 2008. Pengaruh ekstrak kemangi (Ocium basilicum forma citratum) terhadap perkembangan lalat rumah (Musca domestica) (L). Jurnal Entomologi 5(1): 36-44.

Kartasapoetra, A.G. 1987. Hama Hasil Tanaman Dalam Gudang. Jakarta: Bina Aksara.

Kartasapoetra, A.G. 1993. Hama Tanaman Pangan dan Perkebunan. Jakarta: Bumi Aksara.

Kastanja, A.Y. 2007. Identifikasi kadar air biji jagung dan tingkat kerusakannya pada tempat penyimpanan. Jurnal Agroforestri 2(3): 29.

Kim, S.I., J.H. Yi., J.H. Tak, and Y.J. Ahn. 2004. Acaricidal activity of plant essential oils against Dermanyssus gallinae (Acari: Dermanyssidae). Journal Veterinary Parasitology 120: 297-304.

Koul, O., S. Walia, and G.S. Dhaliwal. 2008. Essential oils as green pesticides: potential and constraints. Journal Biopesticides International 4: 63-84. 
Lee, S.E., B.H. Lee, W.S. Choi, B.S. Park, J.G. Kim, and B.C. Campbell. 2001. Fumigant toxicity of volatile natural products from Korean spices and medicinal plants towards the rice weevil, Sitophilus oryzae (L). Pest Manag Scie 57(6): 48-53.

Mangoendihardjo, S. 1978. Hama dan Penyakit Pascapanen. Fakultas Pertanian. Yogyakarta: Universitas Gajah Mada.

Manohara, D., D. Wahyuno dan Sukamto. 1994. Pengaruh Tepung dan Minyak Cengkeh terhadap Phytophthora, Rigidoporus dan Sclerotium. Bogor: Balai Penelitian Tanaman Rempah dan Obat.

Manueke, J., M. Tulung, dan J.M.E. Mamahit. 2015. Biologi Sitophilus oryzae dan Sitophilus zeamais (coleoptera: curculionidae) pada beras dan jagung pipilan. Jurnal Eugenia 21(1): 21-26.

Mika, M., K. Sumiartha, dan Susila. 2012. Efikasi minyak atsiri tanaman cengkeh (Syzygium aromaticum (L.) Meer. \& Perry), pala (Myristica fragrans Houtt), dan jahe (Zingiber officinale Rosc.) terhadap mortalitas ulat bulu gempinis dari Famili Lymantriidae. Jurnal Pertanian 1: 12-23.

Murdolelono dan Hosang. 2006. Pengaruh teknik penyimpanan terhadap kualitas benih jagung lamuru dan lokal di Propinsi Nusa Tenggara Timur. Jurnal Pengkajian dan Pengembangan Teknologi Pertanian 9(2): 207-220.

Natawigena. 1990. Entomologi Pertanian. Bandung: Orba Sakti.

Natawigena. 2000. Pestisida dan Kegunaannya. Bandung: Penerbit Armico.

Nurdjannah, N. 2004. Diversifikasi penggunaan cengkeh. Balai Besar Penelitian dan Pengembangan Pasca Panen Pertanian 3(2): 61-70.

Nurjannah, D.A., R. Retnowati, dan U.P. Juswono. 2013. Aktivitas antioksidan dari minyak bunga cengkeh (Syzygium aromaticum) kering berdasarkan aktivitas anti radikal yang ditentukan menggunakan electron spin resonance. Journal Kimia Student 1(2): 283-288.

Nursal, E. 1997. Pengaruh Konsentrasi Ekstrak Bahan Pestisida Nabati terhadap Hama. Bogor: Balai Penelitian Tanaman Obat.

Nyoman, I. 2005. Pengendalian Hama Terpadu dan Implementasinya di Indonesia. Yogyakarta: Gajah Mada University Press.

Octavianty, Y. dan Suwarto. 2010. Budi Daya Tanaman Perkebunan Unggulan. Jakarta: Penebar swadaya.

Putri, V. B. 2004. Kajian Daya Insektisida Alami Daun Sirsak, Daun Srikaya, Daun Mahoni, Daun Bunga Kecubung terhadap Perkembangan Serangga Hama Gudang Sitophilus zeamais Motsch. Skripsi (Tidak dipublikasikan). Bogor: Institut Pertanian Bogor.

Pranata, R.I. 1979. Pengantar Ilmu Hama Gudang. Bogor: Biologi Tropika.

Sari, M. 2013. Uji efektivitas beberapa insektisida nabati untuk mengendalikan ulat grayak (Spodoptera litura F.) (Lepidoptera: Noctuidae) di laboratorium. Jurnal Online Agroekoteknologi 1(3): 2337-6597.

Saenong, M.S. 2013. Pemanfaatan Pestisida Nabati untuk Pertanian dan Kesehatan. www.peipfi-komdasulsel.org/wpcontent/uploads/2013/01/9-Pemanfaatan-pestisida-nabati.pdf Diakses tanggal 5 Januari 2018.

Setyowati, D. 2004. Pengaruh macam pestisida organik dan interval penyemprotan terhadap populasi hama thrips, pertumbuhan dan hasil tanaman cabai (Capsicum annum L.). Jurnal Pertanian 6: 163-176.

Soekarna. 1984. Teknologi Pemprosesan, Pengemasan dan Penyimpanan Jagung. Yogyakarta: Kanisius.

Sonyaratri, D. 2006. Kajian Insektisida Ekstrak Daun Mimba (Azadirachta indica A. Juss) dan Ekstrak Daun Mindi (Melia azedarach L.) terhadap Perkembangan Serangga Hama Gudang (Sitophilus zeamais Motsch. Skripsi (Tidak dipublikasikan). Institut Pertanian Bogor. Bogor.

Sudarmo, S. 2005. Pengendalian Serangan Hama Tanaman Buah. Yogyakarta: Kanisius.

Sukoco. 1998. Daya Hambat Campuran Ekstrak Lada Hitam (Piper ningrum L.) dan Ekstrak Kayu Manis (Cinnamomum burmanii) terhadap Perkembangan Sitophilus zeamais pada Beras Selama Penyimpanan. Skripsi (Tidak dipublikasikan). Institut Pertanian Bogor. Bogor.

Surtikanti, dan O. Suherman. 2003. Reaksi 52 galur atau varietas jagung terhadap serangan kumbang bubuk. Berita Pusat Penelitian dan Pengembangan Pertanian Tanaman Pangan Bogor.

Surtikanti. 2004. Kumbang bubuk S. zeamais Motsch. (coleoptera: curculionidae) dan strategi pengendaliannya. Jurnal Penelitian dan Pengembangan Pertanian Maros 23(4): 123-129. 
Susmawati. 2014. Budidaya Tanaman Jagung (Kajiwidya Di BBPP Binuang). Balai Besar Pelatihan Pertanian Binuang. http://bbppbinuang.info/images/upload/file/Budidaya\%20Jagung.pdf Diakses tanggal 24 Februari 2017.

Thorsell, W., A. Mikiver, and H. Tunon. 2006. Repelling properties of some plant material on the tick Ixodes ricinus L. Journal Phytomedicine 13: 132-134.

Wagiman, F.X. 2014. Hama Pascapanen dan Pengolahannya. Yogyakarta: Gadjah Mada Univesity Press.

Warisno. 1998. Jagung Hibrida. Yogyakarta: Kanisius.

Winarno, F.G., dan B.S.L. Jennie. 1983. Kerusakan Bahan Pangan dan Cara Pencegahannya. Jakarta: Ghalia Indonesia Printing.

Wiratno. 2010. Beberapa Formula Pestisida Nabati dari Cengkeh. Pusat Penelitian dan Pengembangan Perkebunan. Bogor.

Zeng, L., C.Z. Lao., Y.J. Cen and G.W. Liang. 2010. Study on the Insecticidal Activity Compounds of the Essential Oil from Syzygium aromaticum Against Stored Grain Insect Pest. International Working Conference on Stored Product Protection. Laboratory of Insect Ecology. South China Agricultural University. 